\title{
Iowa Statehood Centennial
}

The centennial anniversary of the admission of Iowa to the family of states is just ahead. The close of the first 100 years of statehood will be celebrated by the people in such manner as seems to them befitting.

The occasion will lend itself to celebration in great variety. The beginnings of the State were colorful and interesting. The century and more of history made in the only State that lies wholly between the two great American rivers is crammed full of inspiring lessons. It is worth while to recall and recount the adventures in social construction and home building, to review again the trials and tribulations not only of the pioneers but of the state makers and community architects, and to stress the importance of education of the young people in the history, development, cultural qualities and political ideals and purposes which prevail in Iowa.

It was with this thought uppermost that the Fortyninth General Assembly approved the following concurrent resolution:

BE IT RESOLVED BY THE HOUSE, THE SENATE CONCURRING: That in view of the approaching centennial of the statehood of Iowa, the state having been admitted to the Union on December 28, 1846, the Governor of Iowa is hereby authorized to appoint a committee of nine persons for the purpose of considering and preparing plans for a proper celebration of the Centennial of Iowa statehood during the year 1946, at the capitol of Iowa and in various parts of Iowa, such program for celebration to be of a character suitable to advance the educational and historical interest of the people of the state in development of our state during its first hundred years. Said committee is hereby instructed to prepare plans and programs for such celebration and submit the same to the Fiftieth General Assembly for such action as it may deem proper.

The outbreak of hostilities involving the United States in December, 1941, compelled a more careful study of the program for such centennial anniversary. Gov. Geo. A. Wilson appointed the committee as contemplated, and upon the same placed representatives of the historical agencies, patriotic societies, the press and radio, the 
women, and others. The field to be explored was entirely new.

In the meantime the State Historical Department had actively entered upon the important task of preserving war records and information as to all war activities; and it was at once seen that whatever plans might be made for 1946 would necessarily be contingent upon the progress or winning of the war, and even it might take a special form relating to military activities.

It was known, also, that the State Historical Society, at Iowa City, is engaged actively in publishing material relating to the early history of the State, and is expanding activities in this direction.

The educational department, under the direction of the State Superintendent of Public Instruction, is promoting and urging more of the study of Iowa history in the schools, and the colleges are moving along the same line.

The American Legion, the Daughters of the American Revolution, the Federation of Women's Clubs, and similar organizations are all actively at work.

A great impetus toward a proper celebration was given by the Iowa Association of Local Historical Societies, formed in 1942, for they are especially interested in local historical events.

As the result of meetings held by the committee appointed, a report with recommendations was prepared and presented to the Governor for transmission to the General Assembly, which report fully expresses the views of the committee and is as follows:

Hon. Bourke B. Hickenlooper,

February 4, 1943

Governor of Iowa,

Des Moines, Iowa.

Dear Mr. Governor:

The Forty-ninth General Assembly of the State of Iowa adopted House Concurrent Resolution 23 providing for the appointment by the Governor of lowa of a committee of nine persons for the purpose of considering preliminary plans for the proper celebration said resolution, the Governor appointed the committee making this report to you, and whose names are signed hereto. The last paragraph of said resolution provided that said committee pre- 
pare plans and submit the same to the Fiftieth General Assembly for such action as it may deem proper.

Said committee has had two meetings, and as a result of careful consideration of the provisions of said resolution, and in accordance with the instructions contained therein, we hereby respectfully submit to you, and to the Fiftieth General Assembly through you, our report as follows:

There is no thought of diverting any particle of the thought or energy of the people of Iowa from the great main purpose of helping to win the war.

The celebration of the centennial anniversary of the State of Iowa is, however, an important and worthy object in itself.

Hope is entertained that victory in the war may come at a date considerably in advance of the time for the actual celebration of the Centennial. In such case, the celebration should be planned to combine with the anniversary theme the additional theme of honor to the fighting men who have helped to win the victory.

It is entirely possible that the end of the war, releasing the energy of our people for a Centennial celebration, might come midway between sessions of the legislature.

In such case, it would be advisable to have the machinery for the purpose set up in advance, so that a commission could start to function at once, instead of having to wait for a half year or even a year for the activity to be authorized.

It is for this last reason that we offer at this time a general outline of tentative plans for the celebration of the Iowa statehood Centennial in 1946.

The actual date of the admission of the State of Iowa into the Union was December 28, 1846. The date is most inconvenient, for three reasons: Business activities are congested then, at the close of the calendar year; everyone is busy with holiday festivities and observances; and the weather is likely to be anything but favorable, certainly prohibitive for any outdoor program. Therefore it is suggested that the entire Centennial year of 1946 be devoted to widespread local observances of the anniversary, in which every community of the state can join, and emphasize its own particular part in the progress of Iowa for the 100 years; with perhaps an official recognition of the exact anniversary date, at the state capitol. We assume that the Iowa state fair will signalize the anniversary at its annual exhibition in its own way.

To this end we suggest that every county, every city, every town, every church, lodge, club, association, or other group of any kind, plan to observe, in a manner fitting to its own line of activity, its own anniversary, whether that be for the exact 100-year period or for a greater or less period of time. Many such observances will be held before the year 1946, but when that year comes, then all celebrations should have special reference to the centennial year.

It also is suggested that, in addition to the public schools, all study clubs and other groups in the state which meet regularly should include in their programs of study from now until 1946 something with reference to the history of the state and to its progress in all lines. 
There are numerous books which in whole or in part cover the history of the state quite fully and ably. But from these more extensive works it would be well to make a compendium of the main facts in the state's history, to be published in economical form for the use of teachers and pupils in the public school system.

The State Department of History and Archives, the State Historical Society of Iowa, and the Iowa Association of Local Historical Societies should be expected to give direction to much of this study, as part of their regular activity. The Centennial series of Iowa historical books published by the State Historical Society will be drawn upon for material, including those already published, and the remaining volumes of the series which are to follow.

The purpose is not to promote a merely academic study of state and local history, or a merely commercial advertisement of Iowa, but to represent faithfully all the activities, material and moral, which have gone into the making of a great state; to stimulate state pride; to stir a lively gratitude for the Providential and human influences which have made Iowa what it is today; and to strengthen the purpose of all Iowans to learn from the lessons of the past in order to build Iowa institutions and character even better as the state's second century begins.

Our suggestion is that the observance of Iowa's statehood Centennial should be an All-Iowa affair, covering every branch of legitimate activity, past and present.

To place in effect the preliminary plans and program referred to above, and to consummate other plans that might be prepared in the future, the undersigned committee hereby makes two definite and concrete recommendations:

1. That if the Governor and the Fiftieth General Assembly approve the general program and plan above submitted, the Governor should be authorized to appoint a Centennial Commission to prepare and frame definite plans and programs and to have full charge of the directions of centennial observances in the state. The committee suggest that said Commission should consist of between fifteen and twenty members, one of each members to be appointed from and to represent each of the following organizations or lines of activity:

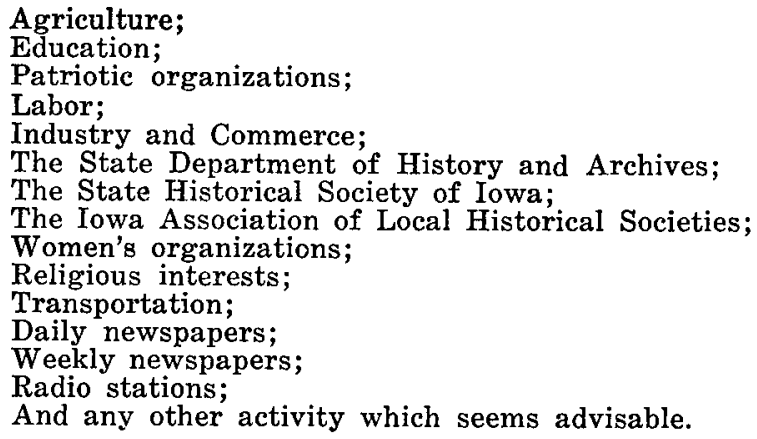


Our second definite and concrete recommendation is as follows:

2. Your committee feels that it would be well for the Centennial Commission to be supplied with a small fund, say one thousand dollars $(\$ 1,000)$ for the biennium, with which to meet actual expenses such as postage, printing, telephone calls, and clerical work. The commission appointments should be completely honorary, with no allowance for time or expenses.

Respectfully submitted

IOWA STATEHOOD CENTENNIAL COMMITTEE

Ora Williams, Chairman-Des Moines

Walter H. Beall-West Union

Robert Burlingame-Des Moines

John W. Carey - Sioux City

Wm. G. Kerr-Grundy Center

Ethyl E. Martin-Iowa City

Frank Miles-Des Moines

Esther Bergman Narey-Spirit Lake

Henry K: Petersion-Council Bluffs 
Copyright of Annals of Iowa is the property of State of Iowa, by \& through the State Historical Society of Iowa and its content may not be copied or emailed to multiple sites or posted to a listserv without the copyright holder's express written permission. However, users may print, download, or email articles for individual use. 